\title{
The Concept of Spiritual Education in Surah Ibrahim Verses 35-41 According to Muhammad Quraish Shihab
}

\author{
Aulia Fitri Yunus ${ }^{1 *}$,Sidik Sidik ${ }^{2}$, and Kamaruddin Kamaruddin ${ }^{3}$ \\ ${ }^{1}$ Islamic Education Department, Postgraduate, Institut Agama Islam Negeri Palu \\ ${ }^{2}$ Islamic Education Department, Postgraduate, Institut Agama Islam Negeri Palu \\ ${ }^{3}$ Islamic Education Department, Postgraduate, Institut Agama Islam Negeri Palu
}

ABSTRACT

This researcher examines the concept of spiritual education according to Muhammad Quraish Shihab in surah Ibrahim verses 35-41 and the relevance of spiritual education in the present context. This type of research is a library research and data collection is done by the method of irfani (Sufism) and analysis approach. Data analysis was performed with inductive analysis techniques, which are drawing conclusions by departing from specific interpretations towards general conclusions. While interpretative is to look for the meaning behind the explicit and implied meaning. The results of the research show that the concept of spiritual education according to Muhammad Quraish shihab in surah Ibrahim verses 35-41 uses the irfani method (tasawuf science) and analysis approach so that it can be seen the meaning of the material and the values of spiritual education contained in surah Ibrahim verses 35-41 namely the value of faith, worship, patience, sincerity, gratitude, and morals. The relevance of spiritual education in the present context of diversity in Islam is the first meaning of the rituals of prayer, fasting, zakat, and pilgrimage. If the rapid development of technology and communication as human beings are required to commemorate each other, advise that they always do the right thing and stay away from the sin. So, current technological developments by looking at spiritual education in the face of social media which are viral can we avoid, but must be multichannel in overcoming the challenges of globalization.
ARTICLE

INFORMATION

Keywords:

Spiritual Education, Surah Ibrahim, Verses 35-41, Quraish Shihab. 


\section{Introduction}

Life can be likened to the light that illuminates the walls of a house, while the spirit is the light. The flow of the spirit and its movements inside the mind is like the movement of the lights in the corner of a house that moves when someone moves it. This spirit is an amazing thing that is rabbani that is not able to know its essence by most human reason.

Al-Nafs is understood as a term that includes the power or power of anger and desire (lust) in humans. In general, this understanding is used by Sufism experts, because they interpret al-nafs as the source of the despicable qualities in human beings. ${ }^{1}$

Spiritual education is oriented to the development of a healthy human soul marked by the presence of a peaceful soul integrity, meridhai and blessed soul (muthmainah, radhiyah, mardhiyah). ${ }^{2}$

Spiritual education is expected to provide the integration of values in body and soul which are the substance of the human person and cannot be separated so that humans are able to carry out their functions perfectly. Thus, it can be said that spiritual education has a central building on potential by synergizing the values of knowledge, emotions and religious practices of a person.

\footnotetext{
${ }^{1}$ Ibid, .30

${ }^{2}$ Hamdani Bakran Adz-Dzaky, Psikoterapi dan Konseling Islam, (Yogyakarta: Fajar Pustaka Baru, 2001),.447
}

Spirituality taken from the word spirit (something that gives life or vitality to a system) refers to a kind of human need to place one's efforts within a clear framework of meaning and purpose. ${ }^{3}$ Spirituality is an innate human potential that makes it connected to a greater power, so that humans feel there is a connection between themselves and the universe, which is applied in a number of values. Spirituality is universal, transetnic, transgeographic, transpolitic, transeconomic and there are no boundaries between one human and another. Therefore if someone has these values of spirituality, he does not see others in a limited space.

Spirituality or religiosity is more directed to the aspects that are in the bottom of the heart, the vibrations of the conscience of the human person, personal attitudes that are difficult to guess or mysteries for others, and as a total taste of one's person. The expression of religiosity is seen from the attitude of religios such as standing solemnly and bowing as an expression of devotion facing God and ready to listen to the divine words in the heart. ${ }^{4}$

Spiritual education can be interpreted as an effort to live in a world centered on the

${ }^{3}$ Danah Zohar, Spiritual Capital: Memberdayakan SQ Di Dunia Bisnis (Bandung: Mizan, 2005),63

${ }^{4}$ J.B. Mangunwijaya, Sastra dan Religiositas (Yogyakarta: Kanisius, 1988),.12 
provisions of Allah and always strive to live by taking part in the attributes of Allah Almighty and always work to bring goodness, safety and prosperity in the world. ${ }^{5}$ All educational processes that provide guidance and direction towards the realization of Islamic values in human life.

Spiritual education as a transmission of religious teachings from generation to generation because this involves not only cognitive aspects (knowledge of religious teachings), but also the affective and psychomotor aspects (attitudes and practices of Islamic teachings) are also essential.

Ibn Kathir's view of surah sajdah verses $15-17$ is a command and obligation to Allah to listen and obey every word and deed. They also always do sunnah prayers at night.

Spiritual education is known as a process of personality education that is based on emotional and spiritual intelligence (ruhaniyah) which is based on self problems. ${ }^{6}$ Balance using emotional and spiritual intelligence in the formation of personality will create perfect human beings, as well as being a people who have individual piety and social piety.

Hasan al-Bana said that spiritual education is tarbiyahruhiyah which aims to

\footnotetext{
${ }^{5}$ Agus M. Hardjana, Religiositas, Agama, dan Spiritualitas (Yogyakarta: Kanisius, 2005),.92

${ }^{6}$ Abdul Munir M, Nalar Spiritual Pendidikan Solusi Problem Filosofis Pendidikan Islam (Yogyakarta: Tiara wacana, 2002),.73
}

strengthen the ranks of ta'aruf. ${ }^{7}$ The purpose is to strengthen the soul and spirit, anticipate customs and traditions, continue to maintain good relations with Allah, and always ask for help from Allah. Without prejudice to its activities in life in the world, in other words, it always keeps the balance of the needs of the world and the hereafter.

Said Hawwa included heart education into the concept of Ruhiyah education, and according to him to educate the heart through several stages, as the stages developed in the process of traveling to Allah SWT. ${ }^{8}$

$$
\text { Spiritual education is based on }
$$
experience carried out consciously to direct the spirit so that it continues to run in accordance with his nature that is believing in Allah and developing divine potential to the peak of faith in Allah, so that the spirit can also encourage physical activities or daily actions to always run according with Shari'a.

The term "spiritual" here simply refers to a person's rational belief in his selfidentity as a metaphysical self which is fundamentally different from the body,

\footnotetext{
${ }^{7}$ Triyo Supriyatno, Humanitas Spiritual Dalam Pendidikan (Malang: UIN Malang Press,2009),.124

${ }^{8}$ Said Hawwa, Pendidikan Spiritual, (Cet I; Mitra Pustaka,Yogyakarta 2006),.111
} 
including the brain, matter and all the parts that make up the body. ${ }^{9}$

According to Islam, spirituality refers to the process of wandering ruhaniyah through deep elaboration of shari'ah conformity which is the formal order of religion (exoteric) and Sufism of the esoteric dimension of Islam which bases itself on inner experience. ${ }^{10}$ More specifically, functionally the relationship with God is the way, and spirituality is the light of the way. ${ }^{11}$

God has bestowed humanity with the basic nature through the holy spirit, so that Islam requires fasting (controlling lust) to restore the idolatry (Eid al-Fitr) described by the Prophet to us like a newborn baby, born into the world of this earth by bringing a sacred spiritual basis and healthy according to the laws of heredity. Sin and the changes that occur to it are "accidental" that have nothing to do with their basic nature. It is an act of violence against nature or misorientation and deterioration of instincts that not only causes mental illness but also impedes the independence of his soul.

12

9 BKWSU Group, "Consciousnes From A Spiritual Perspective "dalam PURITY, vol XX, No.11, Agustus 2001, 6.

${ }^{10}$ Azyumardi Azra, Menuju Masyarakat Madani (Bandung: PT. Remaja Rosdakarya,1999),38.

${ }^{11}$ Tariq Ramadan, Menjadi Modern Bersama Islam; Islam, Barat, Dan Tantangan Modernitas (Bandung: Mizan,2003),Xxv.

${ }^{12} \mathrm{Abu}$ Sangkan, Berguru Kepada Allah (Jakarta: Patrap Thursina Sejati,2006),63.
The ideal Islamic education is transcendent and integral, it does not separate physical and metaphysical realms, because the two are interdependent. Education must be able to train students' feelings so that in life attitudes, actions, decisions and approaches to all kinds of knowledge, they are strongly influenced by spiritual values. ${ }^{13}$

Muhammad Quraish Shihab was born on February 16 in Si Dendeng Rappang Regency, South Sulawesi, about 190 Km from Ujungpandang City. ${ }^{14} \mathrm{He}$ comes from an educated Arab descendant. Shihab is his family name (his father) as is commonly used in the Eastern region (Indian subcontinent including Indonesia).

Muhammad Quraish shihab grew up in a Muslim family environment that was devout at the age of nine, he was accustomed to following his father while teaching. His father Abdurrahman shihab (1905-1986) was a person who formed a lot of personality and even later science. He completed his education at jam'iyyah al-Khair Jakarta, the oldest Islamic education institution in Indonesia. His father was a professor in the field of interpretation and had served as

\footnotetext{
${ }^{13}$ Syed Sajjad Husain Dan Syed Ali Ashraf, Krisis Pendidikan Islam (Bandung: Risalah Gusti,1986),2.

${ }^{14}$ M.Quraish Shihab, Membumikan AlQuran..., H. 6, Saiful Amin Ghafur, Profil Para Mufassir Al-Quran (Yogyakarta: Pustaka Insane Madani, 2008),.236
} 
Chancellor of IAIN Alauddin Ujung

Pandang and also as a founder of the Ujung Pandang Indonesian Muslim University (UMI). ${ }^{15}$

Prophet Ibrahim always gave all the tests of his life to Allah, accompanied by prayers that were said. For example, when the prophet Ibrahim left his wife and son (Siti Hajar and the prophet Ismail) whom he loved so much in a barren and tree-free area, but because it was at the command of Allah, prophet Ibrahim did it willingly to welcome Allah's call. ${ }^{16}$

The hadiths related to spiritual education are:

عن ابى يحي سحيب بن سنا ن قال : قال رسول ا الله صلى الله عليه وسلم : عجبا لا مر المو من ان الما ا مر ه كله خير و ليس ذ ا ك لا حد ا لا للمو من ا

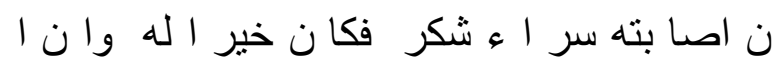
صا بته ضر اءء صبر فكان خير الله

That means:

"From Abi Yahya Suhaib son of Sinan ra said: That the Prophet Muhammad said:" It is amazing, in fact all the affairs of the believer is full of kindness, if he gets pleasure he is grateful, then it becomes good for him; and if afflicted with difficulties he also

\footnotetext{
${ }^{15}$ Alwi Shihab, Islma Inklusif: Menuju Terbuka Dalam Beragama ( Bandung: Mizan,1999),.V

${ }^{16}$ Muhammad Rusli Amin, Jangan Abaikan Doa Ayah (Jakarta 2010),
}

be patient, then it will be good for him. "(HR. Muslim). ${ }^{17}$

From the above hadith we can find at least two important keywords in spiritual education, namely to be patient and grateful.

The essence of spiritual intelligence is the effort of someone as a creature of God to believe in the existence of Allah. People who have spiritual intelligence have good self-control, are not selfish, let alone act wrongfully to others. The motivations that drive him to do something are also very unique namely knowledge and truth, as can be seen from the life history of the prophets and the biographies of intelligent and creative people usually have high moral integrity, piety and of course also spiritual integrity. ${ }^{18}$

In modern times, intellectuals try to bring forth the theory of intelligence to face and solve problems of meaning and value, as people know, spiritual intelligence (Spiritual Qoution) or abbreviated as SQ. Spiritual intelligence is related to the ability to meet the needs of the human spirit, in the form of worship so that he can return to his creator in a holy state. So spiritual intelligence is the intelligence of the heart that is related to one's inner quality. This intelligence directs someone to do more human, so they can

\footnotetext{
${ }^{17}$ Abdul Wahid Hasan, Al-Hadis AlTarbawiyah (Pamekasan: AWVA Press (Bukan Anggota IKAPI), 2017,.33

${ }^{18}$ Hamka dalam Tafsir Al-Azhar, juz XVIII, (Surabaya: bina ilmu, 1999), 151.
} 
reach noble values that have not been touched by the human mind. ${ }^{19}$

Humans realize that happiness as a subjective feeling is more determined by a sense of meaning. Meaningfulness for other humans, for nature, and especially for the great power that humans realize is God. Humans are looking for meaning, this is an explanation why in a state of pain and misery some people can still smile. Because happiness is created from a sense of meaning, and is not synonymous with achieving goals.

\section{Literature Review}

\subsection{Previous Study (subheading)}

Spiritual education is the strengthening of spiritual strength for children and the cultivation of faith in themselves as a form of fulfilling their religious instinctual needs, managing their nature with manners and increasing their tendencies (determination, talents), and direct them to the spiritual values, principles, and role models they get from true faith in Allah, his angels, books, apostles, the last days, and their good and bad destiny. ${ }^{20}$

Spiritual based education in this paper is defined as a concept, an education

\footnotetext{
${ }^{19}$ Abdul Mujib, Yusuf mudzakkir, Nuansanuansa Psikologi Islami , ( Jakarta : Raja Grafindo Persada, 2002),33.

${ }^{20}$ Abdul Hamid, Usus al-Tarbiyah alIslamiyah fi al-Sunnah al-Nabawiyah, Tunis: Dar alArabiyah lil Kitab, 1984,.68-69
}

system that emphasizes the development of spiritual or spiritual abilities with spiritual standards that can be felt by students to achieve the perfection of life according to Islamic standards. The development of spiritual abilities is not limited to students, but includes all educational practitioners. This departs from the assumption that educating and following education is worship. Worship functionally aims at spiritual enlightenment.

Spiritual Based Education is based on the belief that educational activities are worship of Allah SWT. Humans were created as servants of Allah and were given the mandate to maintain the sanctity. In general, spiritual-based education focuses on spirituality as the main potential in driving every action of education and teaching, in this case understood as a source of inspirational normative in educational and teaching activities, and at the same time spirituality as an educational goal. ${ }^{21}$

Actually true spiritual education is described as one of the measuring tools (standard measure) in developing various kinds of human personalities with a complete growth / development (including all things), is a source of guidance for reason. With faith in Allah SWT and validate Him (His monotheism), and clarity

\footnotetext{
${ }^{21}$ Ahmad Rivauzi, Pendidikan Berbasis Spiritual; TelaAbdurrauf Singkel dalam Kitab Tanbihal-Masyi, (Tesis), Padang: PPs IAIN Imam Bonjol Padang,2007,.91
} 
of the soul with peace and calm, purify morals by beautifying themselves with virtue, moral values, and good role models, cleanse the body by using it in the right path and prevent it against immoral behavior and abominable behavior, and encourage it to worship and do good deeds that benefit individuals and groups (society), and also a good relationship with others in the community with the presence of solidarity, synergy (mutual support), and mutual helping each other with kindness and piety. ${ }^{22}$

Howard gardner, the originator of the theory of multiple intelligences, chose not to include spiritual intelligence into "intelligence" because it was against scientific codification of measurable (quantitative) criteria. Instead Gardner suggests a suitable "existential intelligence". Gadner's partners have responded by researching existential thought charts as a basis for spirituality. However, Gadner forms a scientific foundation in the discipline of educational theory and interdisciplinarity, which results in the emergence of discourse on spiritual intelligence. $^{23}$

\footnotetext{
${ }^{22}$ Toto Tasmara, Kecerdasan Ruhaniah (Transendental Intelligence) Membentukkepribadaian yang bertanggung jawab, Profesional, dan berakhlak, Jakarta: Bina Insani Press,2001,.35-36

${ }^{23}$ Wigglesworth, Cindy.2002.Spiritual Intelligence And Why It Matters. Dalam Conscious Pursuits Html Diakses Tanggal 3 Agustus 2018
}

Basic knowledge that needs to be understood is that spiritual intelligence is not necessarily related to religion. And people who have a good spiritual intelligent will match between the heart, words, and deeds, in harmony with what is in his heart, words and deeds.

M.Quraish shihab further explained that the potential of the heart includes the potential to be able to reach inspiration and nur / light of God. The first principal tool for knowing in material objects is the ear and eyes, the main tool for obtaining immaterial knowledge is the heart. Knowledge in reality has an invisible aspect of being whose eyes and minds cannot grasp it. Many essences of knowledge cannot be reached by the senses and mind, such as inspiration and revelation. The truth of inspiration and revelation is not easily accessible to the senses and minds, and will be more easily captured / understood by using the potential of the heart. $^{24}$

The author's analysis that spiritual intelligence is used in placing values, means that each individual can position himself to form good behavior.

Ary Ginanjar defines spiritual intelligence as:

The ability to give meaning to worship for every behavior and activity through steps and thoughts

\footnotetext{
${ }^{24}$ Suparlan, Mendidik Hati Membentuk Karakter, (Cet I Yogyakarta 2015),.32
} 
that are natural, to be human, and have a monotheistic mindset (integralistic), and principled only because of Allah. ${ }^{25}$

Spiritual intelligence can be implemented if humans are able to behave properly according to the nature of the soul so that they have a good mindset in drawing closer to Allah.

According to Toto Tasmara:

Spiritual intelligence is a person's ability to listen to his conscience or the whisper of divine truth in the way he makes decisions or makes choices, empathizes, and adapts. Spiritual intelligence is largely determined by efforts to cleanse and enlighten the heart so that it can provide advice and direction of action and how we make decisions. ${ }^{26}$

Every human being has a mind and thought, but people's ability is not all the same in thinking. Some have hard thoughts and hearts and some are soft. All depends on the human personality in acting. Sinetar:

Meanwhile according to Marsha

Spiritual intelligence is thought inspired by the encouragement and effectiveness, the existence or life of the divinity that unites us as its parts. ${ }^{27}$ Furthermore, Marsha Sinetar said that spiritual intelligence is

\footnotetext{
${ }^{25}$ Ary Ginanjar Agustian, Rahasia Sukses Membangun Kecerdasan Emotional dan Spiritual (ESQ), (Jakarta: Penerbit Arya, 2001),.57

${ }^{26}$ Toto Tasmara, Kecerdasan Ruhaniah, (Jakarta: Gema Insani Press, 2001),.47

${ }^{27}$ Marsha Sinetar, Spiritual Intelligence, (Jakarta: PT. Gramedia, 2000),. 12
}

light, the kiss of life that awakens our sleep lives. ${ }^{28}$

Spiritual intelligence involves the ability to live the deepest truth. That means realizing the best, whole, and most humane thing in the mind. Ideas, energy, values, vision, encouragement and direction of the vocation of life flow from within, from a state of consciousness that lives in love. This means, that spiritual intelligence makes humans to live with others with love, sincerity, and ihsan which all lead to the Divine. $^{29}$

Definitively, spiritual education seems to have been widely stated by various experts. Ahmad Suhailah argued that spiritual education is the inculcation of Allah's love in the hearts of students which makes them expect the pleasure of Allah SWT in every words, deeds, attitudes, and behavior, then away from the things that cause His wrath. ${ }^{30}$

\section{Abu Bakar Aceh defines spiritual} education as an effort to seek a relationship with Allah through the process of education and training so that one can meet (liqa') and

\section{${ }^{28}$ Marsha Sinetar, Spiritual Intelligence,. 49}

${ }^{29}$ Abdul Wahab H.S. dan Umiarso, Kepemimpinan Pendidikan dan Kecerdasan spiritual, 49-50.

${ }^{30}$ Ahmad Suhailah Zain al-'Abidin Hammad, Mas'uliyah al-Usrah fi Tahhin al-Syabab min al-Irhab (Lajnah al-'ilmiyah li al-Mu'tamar al-Alami 'an Mauqif al-Islam min al-Irhab, 2004/1425H), 4. 
unite oneself with His Lord. ${ }^{31}$ The Sa'id Eve defines spiritual education in Islam as an effort to cleanse the soul towards Allah SWT. From a dirty soul to a clean soul, from a mind that has not been subject to the Shari'a to a mind that is in accordance with Shari'a, from a hard and diseased heart to a calm and healthy heart, from a spirit that moves away from the door of Allah SWT negligent in worshiping and not really doing it, towards the spirit that knows Allah SWT, always exercising the rights to worship Him, from the physical that does not obey the Shari'a rules to the physical which always holds the Shari'a rules of Allah SWT. ${ }^{32}$

According to Imam Ghazali the quality of the heart, clean or dirty, bright or dark is very dependent and determined by human behavior itself. It is said if he loves religion and likes to do goodness then his heart is clean and bright ${ }^{33}$

Human nature has been created (held / born) by Allah SWT, and He has called for in their self-nature the natural tendencies of faith, monotheism and diversity.

The important effects of spirit education are as follows:

\footnotetext{
${ }^{31}$ Abu Bakar Aceh, Pengantar Ilmu Tarekat: Kajian Historis tentang Mistik (Solo: Ramadhani,1996), 42.

${ }^{32}$ Sa'id Hawwa, Tarbiyatu al-Ruh\}iyah (Kairo: Maktabah al-Wahbah, 1992),.69.

${ }^{33}$ A Ilyas Ismail, True Islam Moral Intelektual Spiritual, (Cet I ; Jakarta 2013),.396
}

\section{Sincere to Allah SWT}

One of the most important influences of true spirit education is to instill sincerity in a believer, by making his intentions, words, and actions carried out sincerely for Allah SWT, he does not seek it except Allah's pleasure, they are free from the desire to seek pleasure, glory, and worldly things.

Indeed sincerity to Allah SWT in all goals and efforts will establish a direct and lasting relationship with Allah SWT, and purify the soul of a believer and cleanse himself, and make him a pious servant in his religion and his world for himself his family, and each individual society where he lives, and make it always obey and pay attention to his Lord in every movement and condition and he faces him with all his soul, with dhikr in his oral, by taking lessons in his mind, his resolve, and with all the deeds and efforts he did through his hands and feet. ${ }^{34}$

\section{Tawakkal (Submission) to Allah SWT}

Tawakkal to Allah will spread in a believer peace, tranquility and comfort, it is related to mental health, intellect and health of the body because it is resignation to Allah guarding themselves from fears, mental illness, frustration, tendencies, the pressure of the mind that can make human happiness

\footnotetext{
${ }^{34}$ Ahmad Juntika Nurihsan, Bimbingan dan Konseling: Dalam Berbagai Latar Kehidupan, Bandung: Refilika Aditama, 2006 hal. 67-68
} 
into distress and suffering, their calmness becomes chaos, optimism becomes pessimistic, positive things become negative and success becomes a failure. ${ }^{35}$

Surely resignation to Allah SWT is important for the soul, mind and body that is needed for every human being both capable and weak people, those who judge and are judged, big or small, male or female, knowledgeable or charity, all need Allah SWT because $\mathrm{He}$ is able to grant their prayers and can fulfill their requests, help them improve, and alleviate their sufferings.

\section{Istiqomah}

One important influence in spiritual education is the formation of istiqomah habits for a believer, which means that he always does all the commands of Allah and away from all his prohibitions, and keeps His rules, and he always feels the existence of God (the existence of Allah ) at all times and places, and encourage himself to seek His pleasure in all deeds and always put his trust (facing) to Him with all his intentions, with that the habit istiqomah stuck in him and run throughout his life, and always refers to Al-Qur'an and the Last Sunnah of the Prophet Muhammad SAW in terms of what appears (dhahir) and which is hidden (inward), and in intention and charity, in purpose and manner, as well as in religion and the world.

Just as this istiqomah habit has a positive influence on people's lives, if this habit applies to each individual community, it will spread a sense of security, and comfort and be included in a society of compassion, love for others, solidarity, tolerance, and integration, and awake from the elements that damage, divide social relations, and morals that are despicable. ${ }^{36}$ Tell the good and oppose (forbid) munkar.

The most important influence, or the most mature fruit of the education of the spirit, is the principle of "ordering the goodness and contradictions of negativity" that gives the greatest influence in the education of a believer, in implanting his head and guarding him from misrepresentation, mistakes, and immorality, while in the life of society it guards it from the elements that destroy, and undermine the dignity caused by the spread of damage, ugliness, and evil which is visible or hidden. ${ }^{37}$

With efforts to familiarize children with the principle of amar ma'rif nahi mungkar, efforts to spread moral values in

\footnotetext{
${ }^{36}$ A. Haidar Putra Daulay, Pemberdayaan Pendidikan Islam di Indonesia, Jakarta: Rineka Cipta, 2009, hal. 53-54
} 
social life, and with efforts that make human life based on purity, cleanliness, and explain guidance, all it becomes a guard against opposition, division, deviation, and protection from all damage, loss and error.

The heart is also the most important element in influencing human behavior. With this heart humans are able to differentiate between good and bad. The heart is like a torch for humans, if the human being is able to use the eyes of his heart. The heart is the place of the spirit, which is first affixed by Allah to supervise human actions. According to Amir al-Mu'minin Ali, qalb has the equivalent meaning Shadr, Fu'ad, Lubb and Syagaf. Shadr is the place where nur (light) is published, Fu'ad is the place where the ma'rifah is published to Allah, $L u b b$ is the place where monotheism is published, and shahghaf is the place where human love for each other is published. ${ }^{38}$

Heart in Arabic is called qalb which is derived from the verb qalaba inqalaba and qallaba which means to turn around, change or move around, the plural is qulub. ${ }^{39}$ In Sufi terminology, the heart is a spiritual heart, because the heart is an embodiment of different aspects of Allah, which describes an aspect related to Allah and beings. $\mathrm{He}$

${ }^{38}$ Musa Asy'arie, Manusia Pembentuk Kebudayaan dalam al-Qur'an, (Yogyakarta: LSFI, 1992), 100.

\footnotetext{
${ }^{39}$ Ibnu Manzur, Lisan al-Arab, Jilid XII, (Mesir: Dar al-Mishriyyah, 1968), 179
}

accepts gifts from Allah and communicates them to creatures.

The Prophet's hadith is said that "If a lump of meat is good, it will be good for the whole body and if the lump is not good then, it will also be a bad body too, remember that it is a human heart" According to Ibn Kathir there are four forms of the human heart including; first, a clean heart like a bright lamp that is the heart of a believer who wants to use the eyes of his heart for the light of his life. Second, a heart that is closed and bound to the lid is the heart of an infidel who does not want to accept the truth. Third, an upside down heart, that is the heart of hypocrites, and fourth, a heart that is layered, a heart in which there is faith and hypocrisy. ${ }^{40}$

Seeing from this meaning, the heart is a place that is in a decisive condition in human actions. Therefore, the heart needs to be educated to inspire spirituality. Spiritual education is intended so that the human spirit that is in the heart is always in contact with Allah at any time, both in the mind of thinking, feeling, and doing.

The method that needs to be done is by way of training the spiritual moral sensitivity that is by way of oral charity, dhikr, praying, istigfar, repentance, think

\footnotetext{
${ }^{40}$ Said Hawwa, Jalan Ruhani, Terj. Khairul Rofie dan Ibn Toha Ali, (Bandung: Mizan, 1995), 59.
} 
positively, always learn from mistakes, and draw lessons from the events experienced. According to Sayyid Qutuhb there are five ways to increase spirituality in the heart, namely: first, increasing the sensitivity of the heart under the reach of Allah who can create anything in this sheet of nature. This is done so that humans always feel that Allah is infinite. Second, to increase the sensitivity of the heart to the continual ownership of Allah, or in other words Allah is always watching him wherever he is and we cannot escape from Him. Third, he remembers the feeling of piety to Allah that is continually in his heart. Fourth, feel love for Allah in order to seek His pleasure. Fifth, sacrifice a feeling of peace with Allah both in adversity and in any circumstance. The goal is an inner contact between himself and Almighty Allah. $^{41}$

One of the characteristics of human beings is to have mind. Allah gives mind to humans to think both formally empirically, and abstractly. The word 'aqal' is derived from Arabic which is formed from the verb 'aqala' which has a binding and restraining meaning. Thus the mind functions to bind and withhold from various human experiences both seen and felt then mixed for conclusions to act. According to Ibrahin

\footnotetext{
${ }^{41}$ Muhammad Quthb, Sistem Pendidikan Islam, Terj. Salman Harun (Bandung: al-Ma'arif, 1993), 5.
}

Madkur, human mind has spiritual potential that can distinguish between the right and the vanity. Therefore, someone who is intelligent is someone who is able to hold back his lust so that his lust cannot takeover himself and he is able to understand the truth, because the person who is controlled by his lust is a person who is prevented from understanding the truth. ${ }^{42}$ The purpose of given mind to humans is to understand the truth that results from empirical or sensory experience as well as abstract experience. Therefore, in the language of boarding school known as "already akil baligh" means Muslims who have been able to distinguish good and bad, right and wrong, rewards and sins, then that person has been subject to law, bearing in mind he has been able to use his mind in his brow life grown.

According to Sa'id Hawwa, mind is divided into two namely taklifi sense and shar'ī sense. Taklifi sense is the lowest intellect possessed by a believer (responsible for his actions later before Allah). Whereas syarri '(perfect sense) is a human restraint of his lusts at the command of Allah. ${ }^{43}$

The ability of the intellect of each person is not the same, there is more and there is less. In this case, he divided his mind

\footnotetext{
${ }^{42}$ Musa Asy'arie, Manusia Pembentuk Kebudayaan dalam al-Qur'an, 99

${ }^{43}$ Said Hawwa, Jalan Ruhani, (Bandung: Mizan, 1995), 62.
} 
into three groups, namely; first people who have a healthy mind, intelligent, and honest in thinking (al-rasikh fi al-ilm) or often called the Kiai (cleric). For such reason the method applied in increasing the spirituality of his mind by inviting the way of Allah by wisdom. Namely expressing strong and convincing grounds so that they know the nature of truth. Such reason usually always seeks the essence of truth which is based on various approaches formulated to understand religion and the universe from the form of a divine image. Second is a group that has a mind that has not been neatly arranged, namely the ordinary lay people. For this they need guidance, and advice that is easily understood, or in other words with the example (uswah). Whereas for the third is the reason of the thinkers (philosophers), this group is only based on the ability of the ratio alone to make an understanding of the truth. They will reject something that is not rational in their view. For this group the method used so that they have spirituality in their thinking by using a pattern of debate that is abstark or postmodersim.

\subsection{Urgency of Spiritual Education}

Spiritual education is the cleansing of the soul or a journey to Allah. According to Said Hawwa the core of spiritual education is the transfer from a dirty soul to a soul that is clean from the mind that has not been subject to the Shari'a to the obedient mind to the Shari'a from a diseased and hardened heart to a calm and prosperous heart from a spirit far from the "door" of Allah, who are negligent in worshiping and are not serious in doing so, towards a spirit that is ma'rifah to Him, always carrying out the rights of worship to Him; from a body that does not obey the rules of the Shari'ah to the physical which always holds the rules of His Shari'ah, both words, deeds or circumstances. ${ }^{44}$

According to Aly Abd Al-Halim Mahmud, spiritual education is an effort to internalize a love for Allah that makes a person only hope for His pleasure in every word, deed, personality, and stay away from everything he hates. ${ }^{45}$

Thus spiritual education has a very close relationship with the discipline of Sufism. According to Ma'ruf Zariq and Ali Abd Al-Hamid Sufism is the knowledge that knows how to purify the soul (tazkiyah alnafs), purification of morals (tasfiyah alakhlak) and build prosperity and happiness eternally both physically and mentally. ${ }^{46}$

\footnotetext{
${ }^{44}$ Said Hawwa, Tarbiyatun Arruhiyah (Beirut : Dar Ammar 1989),.69

${ }^{45}$ Aly Abd Al-Halim Mahmud, al-Tarbiyah al-Ruhiyyah (kairo dar al-Tauzi wa al-Nasyr alIslamiyah 1995),.69

${ }^{46}$ Ma'ruf Zariq Dan Aly Abd Al-Hamid Dalam Abu Al-Qasim Abd Al-Karim Ibn Hawazin Al-Qusyairi Al Risalah Al-Qusyairiyah Fi Ilm AlTasawuf
} 
Sufism is a means to recognize the subject of the human soul whether it is good or bad. If it's still bad, then he must try to fix it, decorate it with the qualities he feels, and how to get to the divine presence. The explanations above, not only explain the bottom line between spiritual education and Sufism, but both of these disciplines discuss and educate the same object.

Islamic education is a study of education which has an important role to be learned by every Muslim, who wishes that education can take place smoothly and achieve goals. The urgency to study Islamic education includes: ${ }^{47}$

1. Islamic education as an effort to shape the human person must go through a long process with results that cannot be known immediately, in contrast to forming inanimate objects that can be done in accordance with the wishes of the maker.

2. Islamic education, in particular, which originates from Islamic religious values, besides instilling and shaping life attitudes that are imbued with these values, also develops the ability to learn knowledge in line with the underlying Islamic values. educate in the direction of maturity that benefits him.
3. Islam as a religion of revelation revealed by Allah with the aim to prosper and make life happy and the lives of humankind in the world and the hereafter, can only have functional and actual meaning in humans if developed in a systematic educational process.

\section{Biography of Muhammad Quraish Shihab}

Quraish shihab was born on 16 February 1944 in Rapang, South Sulawesi. A shady figure with a straight and charismatic figure, with a height of $172 \mathrm{~cm}$, a balanced weight, typical speech, neatly combed black hair, oval face, glasses, and fair skin. He comes from a family of highly educated Arab descendants. His father, $\mathrm{KH}$. Abdurrahman Shihab was seen as one of the educator figures who had a good reputation among the people of South Sulawesi. His contribution in the field of education is evident from his efforts to foster two universities at the point of view, namely the Indonesian Muslim University (UMI), the largest private tertiary institution in the eastern part of Indonesia, and IAIN Alauddin at the point of view, and he is also listed as the rector at both These universities: UMI 1959-1965 and IAIN 19721977. ${ }^{48}$ Informally, often preaching, delivering spiritual splashes to mosques.

\footnotetext{
${ }^{48}$ Hasani Ahmad, Diskursus Munasabah Al-
} Quran, (Cet I; Jakarta Desember 2013),.132 
Besides preaching bi al-verbal, he also did not hesitate to do the preaching bi al-hal or even bi al-amal. So he is very encouraging of the progress of Islamic education in South Sulawesi. In addition to donating Islamic books, he also likes to financially help Islamic educational institutions there.

As an open-minded person, Abdurrahman believes that education is an agent of change. Such an advanced attitude and outlook can be seen from his educational background, namely Jami'at al-Khair, the oldest Islamic educational institution in Indonesia. Students studying at this institution are taught about the ideas of Islamic movement renewal and thought. This happens because this institution has a close relationship with sources of renewal in the Middle East such as Hadramaut, Haramayn and Egypt. Many teachers were brought into the institute including Shaykh Ahmad Sorkati who came from Sudan, Africa. ${ }^{49}$

As the son of a professor, M.Quraish shihab received initial motivation and seeds of love for the field of interpretation studies from his father who often invited his children to sit together. It is at times like this that the father delivers his advice that is mostly in the form of verses of the Qur'an. The little Quraysh shihab has been struggling and loving the Qur'an since the age of 6-7 years old. He must follow the
Qur'an study conducted by his own father. In addition to tell him to read the Qur'an his father also briefly described the stories in the Qur'an. Here, the seeds of his love for the Qur'an began to grow.

Quraish shihab gained much of its intellectual base from the family environment, in this case the strong influence of his father. As stated:

"Our father, the late Abdurrahman shihab (1905-1986) is a professor in the field of interpretation. Aside from being an entrepreneur, since he was young he also preached and taught. Always leaving the time, morning and evening to read the Qur'an and the commentaries. Often he invites his children to sit together. It was at times like this that he delivered religious advice. Many of the tips that I later knew as verses of the Qur'an or the advice of prophets, friends, or experts of the Qur'an, which until now still ring in my ears". ${ }^{50}$

The influence of the importance of science and education was not only obtained from his father, but also came from his mother. In the narration of the Quraish shihab himself, his mother, Asma Aburisah (1912-1984), always encouraged himself and his siblings to study diligently and did not hesitate and got bored reminding them to practice religious teachings, both when they were small or growing up, or already a doctor though. In addition, his success and

${ }^{50}$ Ibid,. 134 
enthusiasm is inseparable from the support of relatives, family and the environment. ${ }^{51}$

His formal education starts from elementary school. After that he went on to junior high school in Malang while becoming a student in Dar al-hadith alfaqihiyyah Islamic boarding school in the same city. In this boarding school too, he found the teacher and murshid, who were considered by him the most influential people besides his father and mother, this was expressed in order to answer who his teacher was, the answers were "very much". However, there are two figures who cannot escape his memory. This was expressed in one of his books, he said to deepen his Islamic studies, at the age of 14 years, the Quraish shihab was sent by his father to alAzhar, Cairo, in 1958 and accepted in the second grade Tsanawiyah. After that, he continued his studies at al-Aazhar University at the ushuludin faculty, majoring in commentary and hadith and finished in 1967 by earning an Lc (bachelor level). Then he continued his studies in the same department and university and won an M.A. in 1969 defending a thesis specializing in "I'jaz alQuran" entitled "al-I'jaz al-Tashri'i al-Quran al-karim (miracles of the Qur'an from a legal standpoint)." 52

${ }^{51}$ Ibid,. 135

${ }^{52}$ Ibid,. 136
In 1973 Quraish shihab did not immediately continue his studies to the doctoral program, but he preferred to return to Makassar, besides he was indeed called home to the point of view by his father who was then serving as rector, to help manage education at IAIN Alauddin. In the course of his time he was the vice rector of academics and student affairs from 1974 to 1980. Besides occupying that official position, he also often represented his elderly father in carrying out certain basic tasks. Successively after that the Quraysh shihab was handed over various positions, such as the coordinator of private tertiary institutions VII in eastern Indonesia in 1967-1980, assistant chief coordinator between the eastern Indonesian police in the field of mental development in 1973-1975, and a series of other positions outside the campus. He still had time to complete several research assignments, including the application of religious harmony in Indonesia (1975) and waqf issues in South Sulawesi (1978)..$^{53}$

In a period of approximately eleven years between 1969-1980, he plunged into various activities while gaining empirical experience, both in academic activities and in various local government institutions, and to realize his ideals he explored interpretive studies. So in 1980 the Quraysh shihab

\footnotetext{
${ }^{53}$ Ibid,. 137
} 
returned to study at al-Azhar's, specializing in the study of the interpretation of the Qur'an. With his eleven years of experience, he doesn't need to finish his doctoral program long. It only took two years to obtain a doctorate in this field precisely in 1982. His dissertation entitled "Nazm alDurar li al-Biqa'i Tahqiq wa dirasah (a study of the Nazm al-Durar (pearl series) by AlBiqa'i) was successfully defended by the title of summa cum laude with the award of mumtaz ma'a the dignity of al-Sharaf al-Ula (exemplary scholar with special achievements).

Seeing his educational background above, overall Quraish shihab has gone through intellectual development under the care and guidance of al-Azhar university from Tsanawiyah, aliyah, bachelor degree, master degree, to doctoral degree. Thus, it is almost certain that the climate and scientific traditions in Islamic studies within the alAzhar University environment have a great influence on the intellectual tendencies and patterns of religious thought. Egypt with alAzhar universities such as Jansen expresses itself as the most orthodox Islamic institution. Besides being the center of the Islamic reform movement, it is also the right place for the study of the Qur'an. A series of popular figures such as Muhammad Abduh and Rashid Ridha are well-known commentators. Indonesian students who continued their studies in Egypt even became Haramayn's rivals in Islamic studies. ${ }^{54}$

Quraish shihab higher education, mostly in the Middle East, Al-Azhar, Cairo by howard M. Federspiel is considered as unique to Indonesia at a time when part of education at that level was completed in the West. Regarding this he said "while researching his biography, I found that he came from South Sulawesi, was educated in an Islamic Boarding School, and received his high education in Egypt at Al-Azhar University, where he received his M.A and Ph.D degrees. This makes him better educated compared to almost all other authors contained in the Popular Indonesian Literature Of The Qur'an and, moreover, his high level of education in the middle east makes it unique to Indonesia at that time where most of the education at that level resolved in the West. He also has an important teaching career at IAIN's perspective, Jakarta and now, he serves as rector at IAIN Jakarta. This is a very prominent career.

1984 was the second phase of the new phase for Quraish Shihab to continue his career. That round he started from the transfer of assignment status from IAIN Ujung Pandang to the Faculty of Usuludin at IAIN Jakarta. Here, he actively taught the

${ }^{54}$ Ibid,. 139 
field of interpretation and ulum al-Qur'an in the bachelor, master and doctoral programs until 1988. In addition to carrying out his main duties as a lecturer, he was also entrusted to hold the position of Chancellor of the Jakarta IAIN for two periods (19921996 and 1997-1998), and sharia board members of Bank Muamalat Indonesia (1992-1999). ${ }^{55}$ After that he was trusted to hold the position of Minister of Religion for about two months in early 1988, the era was reelected and the resignation of President Soeharto, in 1995-1999 was elected as a member of the national research council, from 1998 until now he was appointed as the Council of the Ministry of Islamic Qur'an Indonesian, until then he was appointed as extraordinary ambassador and in full authority of the Republic of Indonesia for the Arab Republic of Egypt and concurrent republic of Djibouti and Somalia, based in Cairo during the reign of president Baharudin Yusuf Habibi. It was here that he devoted most of his most monumental work as a master pice expert on contemporary Indonesian interpretation early writing in Cairo on Friday, June 18, 1999 M. / Rabi alawwal $1420 \mathrm{H}$, and was completed as a whole in the morning in Jakarta Friday 8 Rajab 1423 H. Coinciding with September 5, 2003, the efforts have been completed to

\footnotetext{
${ }^{55}$ Ibid,. 140
}

provide the readers with the interpretation of the Qur'an al-Karim.

The presence of Quraish shihab in the capital Jakarta has provided a new atmosphere and was warmly welcomed by the community. This is evidenced by the various activities carried out in the midst of the community. Besides teaching he also has and is trusted to hold a number of positions outside of campus. Among them are as members of the MPR RI (1982-1987, 19872002), head of the Indonesian Ulema Council (MUI) center (since 1985-1998), members of the national education considerations 1988-1996, members of the national accreditation 1994-1998, director of the cadre MUI scholars 1994-1997. He was also involved in a number of professional organizations including the assistant chairperson of the Indonesian Muslim Scholars Association (ICMI), when the organization was founded. Subsequently he was also listed as an administrator of the sharia sciences association, and a board of consortiums of the religious sciences department of education and culture. Other activities that he does is as the editorial board of Islamic studies: Indonesian Journal for Islamic Studies, Qur'an Ulumul, Ulama's pulpit, and reflections on religious and philosophy studies journals. All of these publications are in Jakarta. As the port of scientific peak not to say the latter, he is the 
founder and also the director of the Al-Quran study center (PSQ) located at Jl. Pisangan, Ciputar Tangerang. ${ }^{56}$

In addition to the above professional experience activities, Quraish shihab is also known as a reliable writer and speaker. Based on a solid scientific background which he traveled through formal education and was supported by his ability to express opinions and ideas in simple, but straightforward, rational, and moderate thinking tendencies, he appeared as a lecturer and writer acceptable to all levels of society. Quraish shihab is indeed not the only expert on the Qur'an in Indonesia, but his ability to translate and convey the messages of the Qur'an in the context of the present and modern makes it better known and superior to other Al-Quran experts.

Quraish shihab is an interpreter who is an educator. His expertise in the field of interpretation is to be enshrined in the field of education. His position as assistant rector, rector, minister of religion, MUI chairman, expert staff of the minister of education, members of the education considerations, writing scientific papers, and lectures are very closely related to educational activities. In other words, he is a scholar who uses his expertise to educate the people. ${ }^{57} \mathrm{He}$ also did this through his attitude and personality

\footnotetext{
${ }^{56}$ Ibid. 143

${ }^{57}$ Ibid,. 144
}

which were full of attitudes and characteristics that were exemplary. His appearance is simple, tawadu', loving to everyone, honest, trustworthy, and firm in principle is part of the attitude that should be owned by a teacher.

4. Concept of Spiritual Education According to Muhammad Quraish Shihab in Surah Ibrahim Verses 35-41

\subsection{Introduction of Surah Ibrahim}

Surah Ibrahim is the 14th surah which belongs to the surah-makkiyah group because it was revealed in Mecca and before hijrah and consists of 52 verses. ${ }^{58}$ Surah Ibrahim consists of 52 verses is the 14th surah in terms of the order of its writing in the Al-Quran manuscripts, while in terms of descending order it is the 70th surah that descended after surah as-Shura and before surah al-Anbiya. ${ }^{59}$

Surah Ibrahim consists of 52 verses. The majority of scholars consider the verses

${ }^{58}$ Surah ini yang diturunkan di Mekkah dan diberi nama surah Ibrahim, diambil dari kisah singkat Nabi Ibrahim yang disebut dari ayat 35 sampai pada ayat 40. Bukan secara kebetulan kalau pada ayat 35 sampai 41 disebutkan pula doa-doa Nabi Ibrahim agar Allah memperlindungi sebagian daripada keturunan beliau yang telah dipilihkannya tempat dilembah yang tidak ada tumbuh-tumbuhan. Keturunan beliau yang dari ishaq telah menimbulkan bani israil dan menurunkan masa, dan keturunan beliau yang dibawahnya berdiam dilembah yang tidak ada tumbuh-tumbuhan itu yaitu yang dari ismail telah menurunkan Muhammad saw.

${ }^{59}$ M.Quraish Shihab, Tafsir Al-Misbah, Pesan, Kesan Dan Keserasian Al-Quran, (Jakarta;2012),.303. 
of the surah as a whole down before the Prophet Muhammad. Migrate to Medina. A small number of scholars excluded verses 28 and 29. Some also added verses 30 because they considered talking about the events of the Battle of Badr which took place after the Prophet. Emigrated to Medina in the 2nd year of Hijri.

Many of the surah begin with the letters Alif Lam Ra, to distinguish them, the names of these surahs are named after certain prophets whose stories are mentioned or where they were sent, such as al-Hijr. This surah is named surah Ibrahim because he talks about the story of the Prophet Ibrahim, although the description of him is found in several other surah.

Ibrahim in question is the prophet Ibrahim, who by some experts is allegedly born in 2893 before the emigration, and died in 2818 before the emigration. His tomb is in the city of al-khalil, Palestine. ${ }^{60}$

According to the Qur'an and its translation by the Indonesian Department of Religion, the Surah Ibrahim consists of 52 verses, including the Makkahyah surah group because it was revealed in Mecca before the emigration. Called the surah "IBRAHIM", because this surah contains the prayer of the prophet Ibrahim As, namely in verses 35 to 41 . This prayer includes: a

\footnotetext{
${ }^{60}$ M.Quraish Shihab, Al-Lubab Makna Tujuan Dan Pelajaran Dari Surah-Surah Al-Quran (Cet I Tangerang Juli 2012),.87
}

request that his descendants establish prayer, kept away from worshiping idols and so that Mecca and the surrounding area becomes safe and prosperous area. The prayer of the prophet Ibrahim As, this has been permitted by Allah Almighty, as has proven its security since ancient times until now. The prayer was offered by him to the presence of Allah after completing building the Ka'bah with his son Isma'il As, in the barren land area of Mecca. ${ }^{61}$

The main points:

\section{Faith}

The Qur'an is the guide of mankind to the path of Allah, everything in this world belongs to Allah; man's denial of Allah does not diminish his perfection; Allah is the almighty power of killing man and raising him up again in a new form; Allah's knowledge includes the born and the inner.

2. Laws

The command to establish prayer and spend some of the assets, both secretly and openly.

\section{Stories}

The story of prophet Musa As. With his people and the story of the ancient apostles.

4. And others

Because the apostles were sent in the language of their own people; the parable of

\footnotetext{
${ }^{61}$ Departemen Agama Republic Indonesia, Al-Quran Dan Terjemahnya, (Semarang: Toha Putra, 1989),.378
} 
the righteous deeds and words; the events of heaven and earth contain wisdom; various kinds of favors of Allah to humans and Allah's promises to the servants who are grateful for Him. ${ }^{62}$

\subsection{Interpretation of Words}

In the Qur'an, Ibrahim, verses 35-41 refer to Tafsir al-Misbah, some important vocabulary that requires an explanation of meaning, which is as follows:

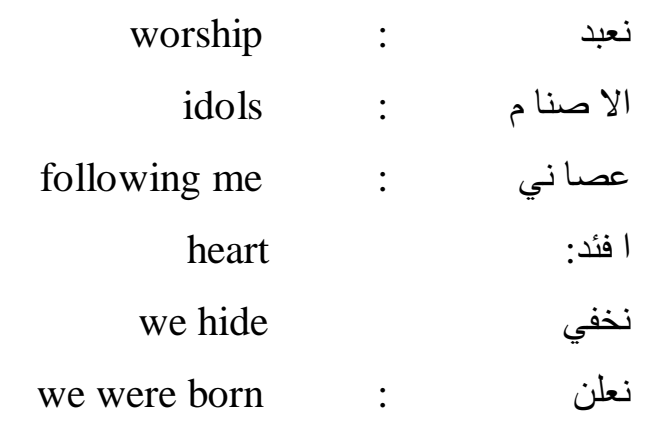

In the view of Sufis, humans tend to follow the passions. He tends to want to rule the world or try to rule in the world. According to Al-Gazali, this way of life will bring people to the brink of moral collapse. ${ }^{63}$ Enjoyment of life in the world has become the goal of the people in general. This view of life causes people to forget their appearance as servants of Allah who must walk on His rules.

To remedy the bad mental state, someone who wants to enter the life of Sufism must go through several stages that are quite heavy. The goal is to master the lust, suppress the lust to the lowest point and

\footnotetext{
${ }^{62}$ Ibid,

${ }^{63}$ Asmaran As, MA,Pengantar StudiTasawuf (Jakarta:RajaGrafindoPersada,1996),h.65
}

if possible turn off the lust altogether. The stages consist of three levels, namely takhalli, tahalli, and tajalli.

In the view of the Sufi opinion that to rehabilitate bad mental attitude requires therapy that is not only from the outward aspect. Therefore, in the early stages of entering the life of Sufism, a person is required to do the practice and spiritual training which is quite heavy the aim is to overcome the lust, suppress the desires, to the lowest point and-if possible- turn off the lust altogether therefore in Sufism morality has a stage of moral guidance system arranged as follows:

\section{Takhalli $^{64}$}

Takhalli is the first step that must be done by a Sufi. Takhalli is an attempt to empty oneself from despicable behavior and morals. One of the most despicable morals that causes bad morals includes excessive love for worldly affairs. Takhalli can also be interpreted to empty himself from the nature of dependence on worldly delights. This can be achieved by distancing yourself from disobedience in all its forms and trying to eliminate the impulse of evil lust.

Takhalli, means emptying oneself from the attitude of dependence on the
${ }^{64}$ Abu Al-Wafa' Al-Ghamini al-Taftazani,. 
delights of worldly life. ${ }^{65}$ In this case, human beings are not asked to totally escape the problems of the world and do not necessarily ask to eliminate lust. But, still take advantage of the world of health as well as their needs by suppressing the impulses that can disturb the reason and feelings. He does not surrender to every desire, does not indulge lust, but also does not turn it off. He places everything in accordance with his proportions, so as not to hunt down the world and not too hate the world.

If the heart has been afflicted with illness or disgraceful qualities, then it must be treated. The remedy is to practice cleansing it first, which is to break away from despicable qualities in order to fill them with commendable qualities to obtain ultimate happiness.

\section{Tahalli}

After going through the stage of selfcleansing from all qualities and mental attitudes that are not good, the effort must continue to the second stage called tahalli. Namely, filling yourself with commendable qualities, by being obedient and inward. ${ }^{66}$.

Thus, this thalli is a soul-filling pond that has been emptied earlier. Because, the arrears of one drink have been released but do not receive a replacement, then the

\footnotetext{
${ }^{65}$ Usman Said, dkk, Pengantar Ilmu Tasawuf ( Medan : Naspar Djaja, 1981 ), h. 99

${ }^{66}$ Asmaran As, MA, Pengantar Studi Tasawuf ,. 69
}

vacancy can lead to frustration. Therefore, every old habit passes, must be immediately filled with one new good habit. From one exercise will become a habit and from habits will produce a personality. The human soul, said Al-Gazali, can be drilled, can be controlled, can be changed and can be formed in accordance with the will of man himself. ${ }^{67}$

Mental attitudes and noble deeds that are very important to be filled in a person's soul and accustomed to in their lives are taubah, patience, infidelity, zuhud, tawakkal, love, ma'rifah, and willingness. ${ }^{68}$ If man is able to fill his heart with praiseworthy qualities, then he will be bright.

Humans are able to empty their hearts from the reprehensible qualities (takhalli) and fill them with praiseworthy qualities (tahalli), all their daily actions are always based on sincere intentions. The whole life and movements of life were given to seek the pleasure of Allah alone. That's why humans like this can draw closer to Him.

Tahalli is an effort to fill and decorate yourself by familiarizing yourself with the attitudes, behaviors, and morals. The stages of tahalli were carried out by Sufis after emptying the soul of despicable

\footnotetext{
${ }^{67}$ Usman Said, dkk, Pengantar Ilmu Tasawuf,.102

${ }^{68}$ Asmaran As, MA, Pengantar Studi Tasawuf ,.71
} 
morals. By carrying out religious provisions both external and internal. The so-called external aspects are formal obligations such as prayer, fasting, pilgrimage and others. And as for that which is in nature is like faith, obedience and love for Allah. it means to rid oneself of the despicable qualities, of immorality and mentality. Among the despicable attributes according to Imam alGhazali are anger, revenge, hasad, miser, mischief, takabbur, and others.

The qualities that illuminate the heart or soul, after the person has cleansed the heart, must also be accompanied by the illumination of the heart so that the dirty and dark heart becomes clean and bright. Because such a heart can receive radiance of Allah's light ${ }^{69}$

When man has cleansed his heart of despicable traits and fills with those praiseworthy qualities, then his heart becomes bright and brighter and that heart can receive light from those praiseworthy qualities. The heart that has not been cleansed cannot receive the light of those praiseworthy qualities. $^{70}$

For the consolidation and deepening of the material that has been passed in the tahalli phase, the next set of moral education is the Tajalli phase. The word tajalli means the unfolding of the supernatural nur. So that

\footnotetext{
Tasawuf,.23

${ }^{69} \mathrm{ftalhah}$, Hasan, Mukhtashar Ilmu

${ }^{70}$ Ibid,.
}

the results obtained by the soul and the organs of the body that have been filled with moral pearls and are accustomed to doing noble deeds - do not diminish, then, the sense of divinity needs to be lived up further. Habits that are carried out with optimum awareness and a deep sense of love will naturally foster longing for Him. as the next second stage, is an effort to fill the heart that has been emptied with another content, namely Allah.

At this stage, the heart must always be occupied with remembrance of Allah. By remembering Allah, letting go of others, will bring peace. There is nothing to fear but the release of Allah from his heart. The loss of the world, for a heart that has been known, will not be disappointed. The time is busy only for Allah, humming in dhikr. At the time of tahalli, because of busyness with remembering and dhikr of Allah in his heart, other members of the body moved by themselves to hum along. His tongue was wet with the lafadz of the greatness of Allah that was endlessly echoed all the time. His hands recite the greatness of his Lord in doing. Likewise, eyes, legs, and other body parts. $^{71}$

At this stage, the heart will feel calm. His anxiety is no longer in a deceptive world. His sadness is not with our children

\footnotetext{
${ }^{71}$ Rosihon Anwar, amukhtar Solihin, ilmu Tasawuf., 56
} 
and wives who will not be with us when death takes us. The pain is not the bodily lust which often rubs off bestiality. But only to Allah. His heart is sad if he does not remember Allah every second.

Tajalli is also a term of Sufism which means "the appearance of God" which is absolute in the form of nature that is limited. This term is derived from the word tajalla or yatajalla, which means "self-proclaimed". Tajali is a pivot point in Ibn'Arabi's thought. In fact, the tajali concept is the basic foundation of Ibn Arobi's view of reality. All Ibn'Arabi's thoughts about the structure of ontology greetings revolved around this axis, and from there developed into a wideranging cosmic system. There is no part in Ibn Arabi's view of reality that can be understood without reference to this main concept. His whole philosophy, in a nutshell, is a tajali theory. ${ }^{72}$

The author will clarify the spiritual education contained in surah Ibrahim verses 35-41. Verse 35 means: And when Ibrahim said: My Lord make this country safe. Including Tajalli because it is an implementation of the prayer request of the Prophet Ibrahim to make it a safe country. The next sentence shows Takhalliyaitu distancing himself and his children from the worship of idols means to stay away from the evil.
Verse 36 means that: My Lord, indeed the idols have misled many people, so whoever follows me, in the words "then surely he belongs to my group, and whoever disobeys me, then you are truly forgiving, merciful, almighty" including Tajallidan there are elements of frivolity because they have followed orders to stay away from the evil and obey the good.

Verse 37 means: Our Lord, verily I have placed a part of my descendants in a valley that cannot have plants near Your honored home, our Lord! That is so that they perform prayers, from the words "then make the hearts tend to them and give them sustenance from fruits, hopefully they are grateful" including Tahallidan Tajalli which shows that there is an element of demand and implementation of gratitude.

Verse 38 means: in the word "our Lord! Surely you know what we hide and what we deliver; and there is nothing hidden from Allah, whether on earth or in heaven "including Tajalli because nothing is done without the command of Allah, meaning to trust Allah more than others (idols).

Verse 39 means that: from the phrase "Praise be to Allah who bestowed on me in the days of Ismail and Ishaq including Tahalli because it shows that his prayer was granted to have the child he wanted, in fact my Lord really heard the prayer. 


\section{Conclusions}

Based on the results of the study and the results of the analysis it can be concluded that: The formulation of spiritual education in the thoughts of Muhammad Quraish Shihab is that there are values of worship, morals, creed, gratitude, patience, and sincerity. The concept of spiritual education according to Muhammad Quraish Shihab in Surah Ibrahim verses 35-41 contained material monotheism, prayer, a good environment, gratitude (faith), sincerity, worship, and love for both parents. The relevance of spiritual education in the present context to the attainment of spiritual education that is all the rituals in the worship relationship are relevant to the present context in accordance with Islamic law.

\section{References}

Al-Maragi Ahmad Mustafa, Tafsir AlMaragi juz XIII, diterjemahkan oleh K. Anshori Umar Sitanggal, dkk., (Semarang: CV Toha Putra, 1994)

Al-Ally, Al-Qur'an dan Terjemahnya, Bandung 2014 Penerbit Diponegoro

Arifin, Dimensi-Dimensi Psikologi Pendidikan, (Surabaya: AlIkhlas, 1994),

Azra,Azyumardi Menuju Masyarakat Madani (Bandung: PT. Remaja Rosdakarya, 1999).

Arifin, Dimensi-Dimensi Psikologi Pendidikan, (Surabaya: AlIkhlas, 1994),

Azra,Azyumardi Menuju Masyarakat Madani (Bandung: PT. Remaja Rosdakarya,1999).

Abu, Sangkan Berguru Kepada Allah (Jakarta: Patrap Thursina Sejati,2006),
Al-Aliyy, Al-Qur'an dan Terjemahnya Penerbit Diponegoro Bandung 2014

Amin Muhammad Rusli, Jangan Abaikan Doa Ayah (Jakarta 2010),.

Azzel Akhmad Muhaimin, Urgensi Pendidikan Karakter Di Indonesia (Jogjakarta; cet III 2014),

Arif,Arifudin M. Cara Cepat Memahami Konsep Pendidikan Dan Pembelajaran Agama Islam PAI (Cet I Sulteng 2014),

al-Farmawi Abd.al-Hay, Metode Tafsir Maudhu'I, ( Yogyakarta : Rake surasin, 1996 ).

Agustian Ary Ginanjar, Rahasia Sukses Membangun Kecerdasan Emotional dan Spiritual(ESQ), (Jakarta: Penerbit Arya, 2001)

Ahmad Suhailah Zain al-'Abidin Hammad, Mas'uliyah al-Usrah fi Tahhin alSyabab minal-Irhab (Lajnah al'ilmiyah li al-Mu'tamar al-Alami 'an Mauqif al-Islam min alIrhab, 2004/1425H)

Aceh Abu Bakar, Pengantar Ilmu Tarekat: Kajian Historis tentang Mistik (Solo: Ramadhani,1996)

Arifi Ahmad (ed), Politik Pendidikan Islam: Menelusuri Ideologi dan AktualisasiPendidikan Islam di Tengah Arus Globalisasi, Yogyakarta: Teras, 2009

Asy'arie Musa, Manusia Pembentuk Kebudayaan dalam al-Qur'an, (Yogyakarta: LSFI, 1992)

Asy'arie,Musa Manusia Pembentuk Kebudayaan dalam al-Qur'an,

Auliya M. Yaniyullah Delta, Melejitkan Kecerdasan Hati dan Otak, (Jakarta: Raja

Grafindo Persada, 2005)

Ahmad Hasani, Diskursus Munasabah AlQuran, (Cet I; Jakarta Desember 2013) Agustian Ary Ginanjar, Rahasia Sukses Membangun Kecerdasan Emotional dan Spiritual(ESQ), (Jakarta: Penerbit Arya, 2001) 
Al-Ghazali Syekh Muhammad, Tafsir AlGhazali: Tafsir Tematik Al-Quran 30 Juz (Yogyakarta: Islamika 2004

Ali H. Muhammad Daud, Pendidikan Agama Islam (Jakarta: Pt Raja Grafindo Persada,2005),

Asmaran As,MA,Pengantar StudiTasawuf (Jakarta:RajaGrafindoPersada,1996)

Abu Al-Wafa' Al-Ghamini al-Taftazani

Asmaran As, MA, Pengantar Studi Tasawuf , ftalhah, Hasan, Mukhtashar Ilmu Tasawuf,

Anwar Rosihon, amukhtar Solihin, ilmu Tasawuf.,

Al-Qurthubi Abdullah Muhammad Ibn Ahmad Anshari (Syaikh Imam AlQurthubi), Tafsir Al-Qutrhubi, Jilid 9, (Jakarta: Pustaka Azzam, 2008)

Abatasa, Pengertian Doa Dan Fungsi Doa, Diakses Tanggal 21 Juli 2018

Ash-Shiddieqy, TM, Hasbi. Kuliah Ibadah; Ibadah Ditinjau Dari Segi Hukum Dan Hikmah (Cet VII; Jakarta Bulan Bintang 1991)

Al-Manhaj ,Menggapai Ridha Allah Dengan Berbakti Kepada Orang Tua Diakses Tanggal 3 Agustus 2018

Bakran Hamdani Adz-Dzaky, Psikoterapi dan Konseling Islam, (Yogyakarta: Fajar

Pustaka Baru, 2001),

Barnadib Imam, Dasar-Dasar Pendidikan; Memahami Makna Dan Perspektif Beberapa Teori (Jakarta: Ghalia Indonesia,1996),

Baidan Nasruddin, Metode Penafsiran alQur'an, ( Yogyakarta : Pustaka pelajar,2002).

Baidan Nasharudin, Tafsir Maudhu'i : Solusi Qur'ani atas Masalah Sosial Kontemporer (Yogyakarta: Pustaka Pelajar, 2001)

Depdikbud Kamus Besar Bahasa Indonesia (online) diakses tanggal $20 \mathrm{Mei}$

Daulay A. Haidar Putra, Pemberdayaan Pendidikan Islam di Indonesia, Jakarta: Rineka Cipta, 2009,
Daulay Haidar Putra dan Nurgaya Pasa, Pendidikan Islam dalam Mencerdaskan Bangsa,(Jakarta: Rineka Cipta, 2012)

Drajat Zakiyah , Ilmu Pendidikan Islam, (Jakarta: PT.Bumi Aksara 2006)

Departemen Agama Republic Indonesia, AlQuran Dan Terjemahnya, (Semarang: Toha Putra, 1989)

Depag RI Tafsir Quran Departemen Agama RI Alquran Dan Tafsirnya Jilid 8, Yogyakarta Universitas Islam Indonesia 1990,

Hawwa Said, Pendidikan Spiritual, (Cet I; Mitra Pustaka, Yogyakarta 2006)

Hardjana Agus M., Religiositas, Agama, dan Spiritualitas (Yogyakarta: Kanisius, 2005),

Husain Syed Sajjad Dan Syed Ali Ashraf, Krisis Pendidikan Islam (Bandung: Risalah Gusti,1986),

Hawwa,Said Pendidikan Spiritual, (Cet I; Mitra Pustaka,Yogyakarta 2006),

Hasan Abdul Wahid, Al-Hadis AlTarbawiyah (Pamekasan: AWVA Press (Bukan Anggota IKAPI), 2017,.

Hamka dalam Tafsir Al-Azhar, juz XVIII, (Surabaya: bina ilmu, 1999),

Hasan Aliah B. Purwakania, Psikologi Perkembangan Islam, (Jakarta: Raja Persada 2006),

Hamid Abdul, Usus al-Tarbiyah alIslamiyah fi al-Sunnah al-Nabawiyah, Tunis: Dar al-Arabiyah lil Kitab, 1984

Hawwa Sa'id, Tarbiyatu al-Ruh\}iyah (Kairo: Maktabah al-Wahbah, 1992).

Hawwa Said, Tarbiyatun Arruhiyah (Beirut : Dar Ammar 1989)

Hanafi Hassan, Metode Tafsir dan Kemaslahatan Umat, Terj, Yudian Wahyudi (Yogyakarta: Pesantren Nawesea, 2007)

Hamka Tafsir Al-Azhar, Jilid 5,

Ismail Faisal, Pencerahan Spiritualitas Islam di Tengah Kemelut Zaman Edan, (Yogyakarta: Titian Wacana, 2008)

Ismail, A Ilyas True Islam Moral Intelektual Spiritual, (Cet I ; Jakarta 2013) 
Ibnu Manzur, Lisan al-Arab, Jilid XII, (Mesir: Dar al-Mishriyyah, 1968)

Kurniasih Imas, Mendidik Anak Menurut Nabi Muhammad, (Cet I Yogyakarta: Galangpress, 2010),

Katsir Ibnu, Tafsir Ibnu Katsir, Jilid 4, (Kuala Lumpur: Victory Agencie, 1988),.499

Kuhsari,Ishaq Husaini al-Qur'an dan Tekanan Jiwa, (Jakarta: The Islamic College,2012)

Lexy J. Moleong, Metode Penelitian Kualitatif, ( Bandung: Remaja Rosda Karya, 1998 ).

M. Quraish Shihab, Membumikan al-Qur'an, (Jakarta : Mizan, 1997).

Mangunwijaya J.B, Sastra dan Religiositas (Yogyakarta: Kanisius, 1988)

Munir Abdul M, Nalar Spiritual Pendidikan Solusi Problem Filosofis Pendidikan Islam (Yogyakarta: Tiara wacana, 2002)

Muhajir Noeng, Metode Penelitian Kualitatif , ( Yogyakarta: Rake Surasin,1996 ),

Marshall Danah Zohar dan Ian, Kecerdasan Spiritual, terj. Rahmani Astuti, dkk, (Bandung:Mizan, 2007)

Mahmud, Aly Abd Al-Halim al-Tarbiyah alRuhiyyah (kairo dar al-Tauzi wa alNasyr al-Islamiyah 1995)

Ma'ruf Zariq Dan Aly Abd Al-Hamid Dalam Abu Al-Qasim Abd Al-Karim Ibn Hawazin Al-Qusyairi Al Risalah AlQusyairiyah Fi Ilm Al-Tasawuf

Muhammad,Su'aib H Pesan Al-Quran,.

Nurihsan Ahmad Juntika, Bimbingan dan Konseling: Dalam Berbagai Latar Kehidupan, Bandung: Refilika Aditama, 2006

Najati,Utsman Belajar $E Q$ dan $S Q$ dari Sunah Nabi,

Najati Muhammad Utsman, Jiwa dalam Pandangan Para Filosof Muslim, (Bandung:

Pustaka Hidayah, 2002)

Najati M. Utsman, Belajar $E Q$ dan $S Q$ dari Sunnah Nabi, (Jakarta: Penerbit Hikmah, 2002)
Nurbakhsy Javad, Psikologi Sufi.Terj. Arief Rakhmat. (Yogyakarta: Fajar Pustaka Baru, 2000)

Quthb Muhammad, Sistem Pendidikan Islam, Terj. Salman Harun (Bandung: al-Ma'arif, 1993)

Quraish Shihab, Tafsir Al-Misbah

Ramadan Tariq, Menjadi Modern Bersama Islam; Islam, Barat, Dan Tantangan Modernitas (Bandung: Mizan,2003).

Raharjo Dawam, Ensiklopedi al-Qur'an: Tafsir Al-Qur'an Berdasarkan Konsep-konsep Kunci (Jakarta: Paramadina, 2002),.

Rivauzi Ahmad, Pendidikan Berbasis Spiritual; TelaAbdurrauf Singkel dalam Kitab Tanbihal-Masyi, (Tesis), Padang: PPs IAIN Imam Bonjol Padang,2007,.

Rada Soleha Dan, Ilmu Pendidikan Islam, (Cet I Bandung 2011).

Ramayulis, Ilmu Pendidikan Islam, (Jakarta, Kalam Mulia, 2002)

Shihab M.Quraish, Membumikan AlQuran..., H. 6, Saiful Amin Ghafur, Profil Para Mufassir Al-Quran (Yogyakarta: Pustaka Insane Madani, 2008),

Shihab Alwi, Islma Inklusif: Menuju Terbuka Dalam Beragama( Bandung: Mizan,1999),

Soleha, Ilmu Pendidikan Islam( cet I Bandung 2011 ),

Suparlan, Mendidik Hati Membentuk Karakter, (Cet I Yogyakarta 2015)

Sinetar Marsha, Spiritual Intelligence, (Jakarta: PT. Gramedia, 2000)

Shihab,M.Quraish "Membumikan Al-Quran (Bandung; Mizan, 1992)

Shihab,M. Quraish Tafsir al-Misbah, Pesan, Kesan dan Keserasian al-Qur'an, Vol. I, (Jakarta: Lentera Hati, 2007)

Shihab M.Quraish, Tafsir Al-Misbah Pesan, Kesan Dan Keserasian Al-Quran,(Cet V Jakarta 2012)

Shihab M.Quraish, Tafsir Al-Misbah, Pesan, Kesan Dan Keserasian Al-Quran, (Jakarta;2012) 
Shihab M.Quraish, Al-Lubab Makna Tujuan Dan Pelajaran Dari Surah-Surah AlQuran (Cet I Tangerang Juli 2012)

Said,Usman dkk, Pengantar Ilmu Tasawuf ( Medan : Naspar Djaja, 1981 )

Shihab,Quraish Tafsir Al-Misbah,

Shihab M.Quraish, Wawasan Al-Quran: Tafsir Maudhu'i Atas Pelbagai Persoalan Umat, (Bandung: Mizan, 1996)

Shiddieqy Hasbi ash-, Kuliah Ibadah, (jakarta : Bulan Bintang, 1954)

Tim Dosen Filsafat Ilmu Fakultas Filsafat UGM, Filsafat Ilmu (Yogyakarta: Liberty,2002),

Tasmara Toto, Kecerdasan Ruhaniah (Transendental Intelligence) Membentukkepribadaian yang bertanggung jawab, Profesional, dan berakhlak, Jakarta: Bina Insani
Press, 2001

Tasmara Toto, Kecerdasan Ruhani:Transcendental Intelligence

Uhbiyati Nur, Ilmu Pendidikan Islam,

Umiarso Abdul Wahab H.S. dan, Kepemimpinan Pendidikan dan Kecerdasan spiritual

WiyanNovan Ardy i, Pendidikan Karakter Berbasis Iman dan Taqwa,.

Yani,Ahmad Be Excellent : Menjadi Pribadi Terpuji, (Jakarta : Al-Qalam, 2007)

Zuhdi M. Nurdin, Corak Tafsir al-Qur'an Mazhab Indonesia (tesis tidak diterbitkan, Yogyakarta: Program Pascasarjana, 2011)

Zohar Danah, Spiritual Capital: Memberdayakan SQ Di Dunia Bisnis (Bandung: Mizan,2005), 